\title{
APAKAH E-WOM (ELECTRONIC WORD OF MOUTH) BISA MENGALAHKAN WOM (WORD OF MOUTH) DALAM MEMPENGARUHI PENJUALAN \\ PRODUK KULINER
}

\author{
Lavenia Hariono
}

Universitas Ma Chung

\begin{abstract}
Globalization has caused a rise of so many technology developments, such as in communication. In past communication can only be used through phone call and short message. Nowadays media social became one of the communication media until promotion media which became the origin of e-WOM. WOM has been successfully becoming one of promotion strategies in the culinary business. Due to technology developments, WOM has a new model that called e-WOM especially in culinary business. Therefore, This article is expected to help marketers who are doing a critical review about e-WOM (Electronic Word of Mouth) and WOM (Word of Mouth) that became controversy in influencing culinary sales. This research method is using literature data.

Keywords: WOM, e-WOM, culinary business, consumer satisfy
\end{abstract}

\section{PENDAHULUAN}

Berdasarkan data yang didapat dari Dispendukcapil kota Malang (2017), jumlah penduduk kota Malang per November 2017 adalah 902.568 jiwa. Data tersebut menunjukan bahwa kota Malang kini menempati urutan ke-10 kota terpadat di Indonesia dan urutan ke-3 kota terpadat penduduk di Jawa Timur dengan pendapatan per kapita yang mencapai 60,881 juta rupiah (Muarif, 2017). Data tersebut menunjkan bahwa kota Malang termasuk ke dalam salah satu kota di provinsi Jawa Timur yang saat ini sedang mengalami kemajuan dalam dunia bisnis. Banyak bisnis yang bermunculan di Malang baik bisnis kecil maupun bisnis besar. Menurut Rutmawati (2017) berdasar data statistik, jumlah UMKM (Usaha Mikro Kecil dan Menengah) di kota Malang mencapai angka lebih dari 70.000, meskipun 90 persen dari angka tersebut masih bergerak di usaha mikro. Hal tersebut berarti persaingan dalam dunia bisnis juga semakin ketat.

Beberapa tahun terakhir ini di kota Malang muncul berbagai bisnis kuliner yang memiliki peminat cukup tinggi. Hal tersebut ditandai dengan semakin banyaknya bisnis kuliner yang bermunculan, mulai dari pedagang jajanan, makanan tradisional, pedagang kaki lima, kafe, restoran atau rumah makan, bisnis katering, hingga kue yang biasa dijadikan sebagai oleh-oleh. Buktinya saja rumah makan di Kota Malang yang tercatat di 
situs resmi Pemerintah Kota Malang saat ini ada 54 (belum termasuk yang tidak tercatat). Pesatnya bisnis kuliner tersebut mengakibatkan terjadinya perubahan gaya hidup pada masyarakat. Masyarakat menjadi lebih memilih untuk makan di luar dengan alasan mencoba kuliner baru.Selain itu ada juga yang memilih makan di luar agar tidak ketinggalan berita mengenai kuliner terbaru.

\begin{tabular}{|c|c|c|c|c|c|c|}
\hline Komponen & 2011 & 2012 & 2013 & 2014 & 2015 & 2016 \\
\hline 1. Pengeluaran Konsumsi Rumah Tangga & 5,13 & 5,12 & 6,47 & 5,84 & 3,59 & 5,04 \\
\hline 2. Pengeluaran Konsumsi LNPRT & 1,73 & 3,95 & 8,51 & 14,95 & $-4,14$ & 3,82 \\
\hline 3. Pengeluaran Konsumsi Pemerintah & 3,12 & 3,95 & 6,25 & 2,89 & 2,22 & $-6,69$ \\
\hline 4. Pembentukan Modal Tetap Domestik Bruto & 5,16 & 7,13 & 6,14 & 4,14 & 7,61 & 6,50 \\
\hline 5. Perubahan Inventori & - & - & - & - & - & - \\
\hline 6. Ekspor Barang dan Jasa & 15,38 & 10,17 & 12,09 & 14,12 & 5,02 & 7,54 \\
\hline 7. Impor Barang dan Jasa & 6,70 & 5,70 & 11,60 & 14,08 & 2,90 & 5,98 \\
\hline PDRB & 6,04 & 6,26 & 6,20 & 5,80 & 5,61 & 5,61 \\
\hline
\end{tabular}

Sumber : www.bps.go.id

\section{Gambar 1. Laju Pertumbuhan PDRB Kota Malang Tahun 2011-2016}

Banyaknya bisnis kuliner yang bermunculan mengakibatkan adanya persaingan ketat diantara pebisnis kuliner. Mereka harus bisa mempertahankan pelanggan agar bisnis kulinernya dapat berlangsung. Berbagai strategi bisnis kemudian dilakukan oleh para pelaku usaha kuliner. Salah 1 strategi adalah melakukan promosi di berbagai media baik di media sosial maupun promosi secara konvensional (dengan membagi brosur, menempelkan poster, dan lain-lain). Selain itu harus meningkatkan kualitas pelayanan dan mutu makanan yang dijual. Bila tidak demikian konsumen akan merasa tidak puas dan tidak akan kembali untuk melakukan pembelian ulang. Lebih parahnya lagi konsumen yang tidak puas akan menceritakan pengalamannya tersebut pada teman-temannya. Kemudian hal tersebut akan menyebar dengan sangat cepat sehingga berdampak pada penurunan penjualan.

Cerita mengenai suatu produk yang tersebar dari mulut ke mulut biasa dikenal dengan istilah WOM. Seiring perkembangan zaman, WOM berkembang menjadi e-WOM (cerita dari mulut ke mulut tapi menggunakan media elektronik). WOM dan e-WOM 
memiliki peran penting dalam mempengaruhi penjualan produk kuliner. Para pebisnis kuliner memanfaatkannya sebagai sarana promosi karena kuliner merupakan suatu produk yang dapat dievaluasi secara verbal dan non-verbal. Biasanya orang akan mencari tahu informasi mengenai tempat dan makananyang akan dibelinya. Informasi tersebut mereka peroleh dari beberapa sumber, seperti media sosial, internet, pendapat orang sekitarnya yang pernah mencobanya, dan lain-lain. Setelah mendapat informasi tersebut, merekaakan memperoleh keputusan untuk melakukan pembelian atau tidak.

Konsumen yang puas dengan suatu produk yang ia beli akan dengan senang hati merekomendasikannya pada orang di sekitarnya. Baik melalui media sosial dan situs internet lainnya (e-WOM) maupun merekomendasikan secara verbal pada orang yang ia kenal (WOM). WOM dan e-WOM yang positif akan berpengaruh pada peningkatan penjualan karena secara tidak langsung konsumen ikut mempromosikan suatu produk berdasarkan pengalaman yang ia peroleh pada konsumen lain. Hal tersebut menjadi pertimbangan orang lain sebelum akhirnya memutuskan untuk membeli suatu produk kuliner. Orang cenderung lebih percaya pada apa yang telah dikatakan oleh konsumen lain daripada iklan. Cerita dari pengalaman konsumen yang pernah membeli produk terdengar lebih menarik sehingga bisa mempengaruhi orang lain untuk ikut mencoba makanan tersebut. Terutama bila yang menceritakan pengalaman tersebut adalah orang yang sudah dikenalinya seperti keluarga, sahabat, teman, saudara, dan lain-lain. Menurut Sumardy et al., (2011), word of mouth diyakini dapat mendorong pembelian oleh konsumen, mempengaruhi komunitas, efisien karena tidak memerlukan budget yang besar (low cost),dapat mencipatakan image positif bagi produk, serta dapat menyentuh emosi konsumen.

Globalisasi telah membawa dampak yang besar pada berbagai sektor, salah satunya adalah pada sektor teknologi komunikasi. Dulunya orang-orang menggunakan media komunikasi hanya sebagai sarana untuk berkomunikasi. Seiring dengan perkembangan teknologi, kini media komunikasi tidak hanya digunakan sebagai sarana untuk berkomunikasi karena terhubung oleh internet. Media komunikasi yang paling banyak digunakan oleh orang-orang adalah media sosial (seperti: Line, Whatsapp, Telegram, Instagram, dan lainnya). Setiawan (2017) mencatat bahwa jumlah pengguna internet di Indonesia mencapai 143.260.000 juta jiwa.Angka tersebut meningkat dibandingkan pada tahun sebelumnya, yakni tahun 2016 yang tercatat mencapai 132.700.000 juta jiwa. 
Perkembangan teknologi komunikasi terutama pada media sosial dan internet yang menjadi cikal bakal munculnya e-WOM. Media sosial dan internet kini merupakan media komunikasi yang memfasilitasi konsumen untuk dapat saling berinteraksi. Interaksi dapat berupa forum diskusi online, rujukan email, hingga ulasan yang diberikan konsumen di berbagai situs internet dan media sosial miliknya sendiri. Hal tersebut mengakibatkan informasi mengenai suatu produk dapat tersebar dengan cepat. Penyebaran informasi oleh konsumen melalui internet dan media sosial dikenal dengan istilah e-WOM. Kini masyarakat cenderung mandiri dengan mencari sendiri informasi mengenai suatu produk di media sosial dan situs internet. Sebelum membeli suatu produk, mereka akan melakukan pencarian mengenai suatu produk dan melihat ulasan mengenai produk tersebut. Informasi yang disebarkan dapat berupa e-WOM positif mhaupun negatif sebagai hasil dari bagaimana pengalaman yang didapatkan oleh konsumen. E-WOM positif dapat mempengaruhi penjualan suatu produk menjadi lebih meningkat karena penyebarannya terjadi di media elektronik. E-WOM negatif dapat mempengaruhi penjualan produk menjadi menurun dalam seketika karena penyebarannya juga di internet. Akibat adanya bentuk baru dari WOM kini masyarakat mulai menggunakan e-WOM karena sebagian besar orang menggunakan internet. Oleh karena itu, artikel ini dibuat dengan harapan dapat membantu pemasar yang sedang melakukan telaah kritis mengenai e-WOM (ElectronicWord of Mouth) dan WOM (Word of Mouth) yang menjadi kontroversi dalam mempengaruhi penjualan kuliner.

\section{TINJAUAN PUSTAKA}

\section{WOM (Word of Mouth)}

Menurut Febiana et al., (2014) WOM (Word of Mouth) adalah tindakan yang dapat memberikan alasan supaya semua orang lebih mudah dan lebih suka membicarakan produk. Sedangkan menurut Hasan (2010:32), pengertian word of mouth dalam dunia bisnis adalah tindakan konsumen memberikan informasi kepada konsumen lain dari seseorang keorang lain (antar pribadi) non-komersial baik merek, produk maupun jasa. Secara garis besar WOM adalah informasi suatu produk yang beredar dari mulut ke mulut yang dapat menghasilkan komentar positif/negatif. Berdasarkan definisi tersebut WOM memiliki peran penting dalam mempengaruhi penjualan produk kuliner. Menurut Budi Wiyono, (2009:1) Word Of Mouth yang beredar terjadi karena :

1. Membicarakan 
Konsumen mungkin saja begitu terlibat dengan suatu produk tertentu atau aktivitas tertentu dan bermaksudmembicarakan mengenai hal itu dengan orang lain, sehingga terjadi proses komunikasi WOM.

2. Mempromosikan

Konsumen mungkin menceritakan produk yang pernah dikonsumsinya, secara tanpa sadar ia turut mempromosikan produk kepada orang lain (teman atau keluarganya).

3. Merekomendasikan

Konsumen mungkin akan merekomendasikan suatu produk yang pernah di belinya kepada orang lain (teman ataukeluarganya).

4. Menjual

Menjual tidak berarti harus mengubah konsumen menjadi salesman layaknya agen MLM tetapi konsumen berhasil mengubah (transform) konsumen lain yang tidak percaya, memiliki persepsi negatif dan tidak mau mencoba merek kita menjadi percaya, persepsi positif dan akhirnya mencoba.

\section{E-WOM (Electronic Word of Mouth)}

E-WOM merupakan salah 1 dampak perkembangan teknologi komunikasi dan merupakan bentuk baru dari WOM. Definisi e-WOM yang sudah diterjemahkan menurut Cheung et al. (2008) adalah lanjutan atau perpanjangan dari komunikasi antar manusia secara tradisional menjadi generasi baru dalam dunia maya. Pelaksanaan e-WOM adalah dalam situs media sosial, tetapi tidak tertutup pada situs lainnya seperti blog hingga situs yang menyediakan forum diskusi. Pada media sosial dan situs internet, konsumen dapat saling bertukar informasi mengenai suatu produk makanan yang pernah mereka coba. Menurut Goyetteet al. (2010) e-WOM terbagi ke dalam tiga dimensi yaitu

\section{Intensity}

Menunjukkan banyaknya pendapat yang ditulis oleh konsumen dalam sebuah situs jejaring sosial, meliputi:

a. Frekuensi mengakses informasi dari situs jejaring sosial.

b. Frekuensi interaksi dengan pengguna situs jejaring sosial

c. Banyaknya Ulasan yang ditulis oleh pengguna situs jejaring sosial.

2. Valence of Opinion 
Didefenisikan sebagai pendapat konsumen baik positif atau negatif mengenai produk, jasa dan merek. Valence of Opinion memiliki dua sifat yaitu negatif dan positif, meliputi :

1. Komentar positif dari pengguna situs jejaring sosial.

2. Rekomendasi dari pengguna situs jejaring sosial.

\section{Content}

Menunjukkan isi informasi dari situs jejaring sosial berkaitan dengan produk dan jasa, meliputi:

a. Informasi Variasi makanan dan minuman.

b. Informasi kulaitas (rasa, tekstur, dan suhu) makanan dan minuman.

c. Informasi mengenai harga yang ditawarkan.

E-WOM dapat tercipta karena kepuasan konsumen terhadap suatu produk dan pelayanan yang diterimanya. Kualitas produk yang tetap terjaga membuat konsumen tidak ingin berpindah ke produk lain. Menurut Kotler dan Armstrong (2012), kualitas produk adalah keamampuan sebuah produk dalam memperagakan fungsinya, hal ini termasuk keseluruhan durabilitas, reliabilitas, ketepatan, kemudahan pengoperasian dan reparasi produk juga atribut produk lainnya. Terutama pada produk kuliner seperti produk kue/jajanan. Konsumen yang akan memberikan oleh-oleh pada orang yang akan dikunjunginya pada umumnya akan melakukan pembelian ulang apabila cocok dengan suatu produk.

\section{Media Sosial}

Teknologi informasi telah mengalami perkembangan yang pesat saat ini. Awal kemunculan media sosial, orang-orang hanya memanfaatkannya sebagai sarana berkomunikasi. Seiring perkembangan waktu dan teknologi media sosial telah menjadi sarana promosi bagi para pemilik usaha/pemasar. Pemasar yang mempromosikan produknya secara online akan menggunakan media sosial sebagai sarana untuk melakukan promosi tersebut. Pemasarakan mengunggah barang yang ia tawarkan, kemudian disebarkan melalui pesan atau fitur photo sharing. Bentuk penawaran ini merupakan perkembangan dari media katalog yang tadinya disebarkan dalam bentuk media cetak.

Menurut Kotler dan Armstrong (2012), media sosial merupakan sarana bagi konsumen untuk berbagi informasi teks, gambar, audio, dan video dengan satu sama lain dan dengan perusahaan dan sebaliknya. Media sosial terdiri dari berbagai macam jenis 
dengan karakteristik yang berbeda, ada yang untuk pertemanan seperti Facebook, Path, Instagram, dan Twitter, ada yang khusus untuk mencari dan membangun relasi seperti yang ditawarkan Linkedin, sampai pada yang lebih pribadi seperti electronic mail (e-mail) dan pesan teks. Situs internet seperti Google, Yahoo, media blog, dan situs probadi juga dapat membantu menemukan berbagai kebutuhan informasi yang diperlukan. Data yang dilansir oleh We are Social, sebuah agensi digital marketing di Amerika, menyebutkan bahwa media sosial yang paling banyak digunakan di Indonesia per Januari 2017 adalah Youtube (49\%) dan oleh Facebook (48\%). Posisi selanjutnya ditempati oleh Instagram (39\%), Twitter (38\%), Whatsapp (38\%), dan Google (36\%). Sisanya ditempati secara berurutan oleh FB Messenger, Line, Linkedin, BBM, Pinterest, dan Wechat (Kemp, 2017).

Media sosial kini menjadi alat komunikasi yang menyatukan komunikasi interpersonal dan komunikasi massa. Hal itu dapat dilihat ketika seseorang mengunggah sesuatu kemudian ditanggapi orang lain kemudian terjadi interaksi, maka terjadilah komunikasi interpersonal. Pada saat yang sama, saat seseorang mengunggah sesuatu apa yang diunggahnya bisa dilihat dan dinikmati semua pengguna internet, sehingga pada saat yang sama komunikasi massa juga terjadi, sebab komunikasi massa tidak mensyaratkan adanya keterlibatan aktif semua pihak (Watie, 2011).

Pemasaran melalui media sosial dapat memudahkan konsumen karena mereka tidak perlu datang ke toko untuk mencari tahu informasi produk, cukup dengan mengakses informasi melalui internet. Hal tersebut dapat menimbulkan terjadinya komunikasi melalui media sosial sehingga menimbulkan pertimbangan bagi pemilik bisnis untuk melakukan pengiklan dan membuat konten online sebagai bahan komunikasi kepada konsumen. Kelebihan lain dari pemasaran di media sosial adalah biaya pemasaran yang rendah, dapat membangun forum sosial yang menciptakan komunikasi interaktif antara penjual dan pembeli, dapat menjangkau target, serta dapat memberikan pelayanan untuk konsumen (Nadaraja dan Yazdanifrat, 2013). Keunggulan lainnya adalah secara tidak langsung media sosial dapat menjadi ajang bagi konusmen untuk membantu mempromosikan suatu produk pada akun media sosialnya, sehingga dapat menarik minat orang yang melihatnya.

\section{Dampak WOM dan e-WOM terhadap Penjualan}

WOM memiliki dampak besar dalam bisnis kuliner, namun terbatas oleh waktu dan tempat sedangkan e-WOM tidak memiliki batasan. Saat ini hampir setiap orang memiliki telepon genggam/HP yang tersambung dengan internet dan selalu dibawa kemana pun. Hal 
tersebut memudahkan siapa pun untuk mendapatkan informasi mengenai suatu produk kuliner dengan mudah. Cukup melakukan pencarian di internet dan media sosial menggunakan nama produk/tempat makan yang akan dituju, maka akan muncul berbagai foto, lokasi, hingga ulasan dari konsumen yang pernah membeli produk tersebut. Sedangkan WOM tidak memiliki keunggulan seperti itu, karena hanya bisa dilakukan apabila bertemu secara langsung. Penyebaran informasi melalui WOM dapat terjadi cesara cepat bila konsumen merupakan orang yang memiliki banyak teman/tergabung dalam komunitas yang sering melakukan pertemuan. WOM yang positif dapat membawa dampak baik bagi penjualan, yaitu dapat menambah penjualan karena orang telah mendengar pengalaman langsung dari orang yang dikenalnya. Sebaliknya jika WOM negatif maka akan berdampak buruk bagi penjualan produk karena orang akan langsung menilai berdasarkan cerita lansgung dari orang yang dikenalnya.

E-WOM merupakan bentuk WOM yang modern karena penyebarannya melalui media elektronik seperti media sosial. Hal tersebut mengakibatkan e-WOM lebih mudah diamati karena dapat dihitung dan dilihat langsung oleh mata (sebab dalam bentuk tulisan serta gambar). Sedangkan WOM hanya bisa dilakukan secara bertatap muka dan melalui pembicaraan langsung. Orang tidak bisa melihat langsung seperti apakah bentuk dan rupa dari produk makanan yang akan dibelinya atau tempat makan yang akan ditujunya. Namun penyebaran WOM tidak dapat terjadi secepat penyebaran e-WOM. Menurut Paludi (2017) e-WOM dapat dilihat dari tiga dimensi yaitu :

1. Kualitas e-WOM

Kualitas e-WOM mengacu pada kekuatan persuasif komentar tertanam dalam informasi pesan. Keputusan pembelian konsumen dapat didasarkan pada beberapa kriteria atau persyaratan yang memenuhi kebutuhan mereka dan untuk menentukan kesediaan mereka untuk membelinya yang didasarkan pada apa yang mereka rasakan dari kualitas informasi yang mereka terima. Oleh karena itu, penting untuk menentukan persepsi konsumen mengenai kualitas informasi sebagai unsur untuk menilai keputusan pembelian potensi mereka.

2. Kuantitas e-WOM

Kuantitas e-WOM mengacu jumlah total diposting komentar. Popularitas produk ditentukan oleh kuantitas komentar online karena dianggap bisa mewakili kinerja pasar suatu produk. Konsumen juga perlu referensi untuk memperkuat kepercayaan 
diri mereka untuk mengurangi kesalahan atau risiko saat berbelanja, dan kuantitas komentar secara online dapat mewakili popularitas suatu produk. Dengan kata lain, konsumen memiliki lebih banyak ulasan mengenai produk yang mencerminkan popularitas dari produk tersebut.

3. Keahlian pengirim pesan e-WOM

Keahlian dapat dilihat sebagai keberwenangan, kompetensi dan keahlian pengirim pesan. Hal ini dianggap bahwa keahlian pengirim pesan ketika mereka membuat komentar dalam review konsumen akan menarik pengguna/konsumen lain untuk mengadopsi informasi tersebut dan membuat keputusan untuk membeli.

Keunggulan e-WOM berikutnya adalah jangkauannya lebih besar daripada WOM. Hal tersebut karena dengan internet semua orang dapat terhubung tanpa batasan geografis sehingga dikatakan memiliki kekuatan seperti media massa. Melalui e-WOM konsumen memiliki banyak kesempatan untuk bertukar informasi tanpa harus saling mengenal. Pada e-WOM keakraban individu tidak diperlukan sehingga identitas tidak harus diungkapkan. Hal tersebut membuat konsumen dapat lebih bebas mengungkapkan pendapat dan ulasan mengenai pengalamannya setelah membeli.

\section{HASIL DAN PEMBAHASAN}

Dalam dunia bisnis WOM terbukti telah berperan penting dalam mempengaruhi keputusan konsumen dalam melakukan pembelian. Hal itu disebabkan oleh pengalaman pribadi yang berasal dari konsumen yang tidak dibayar untuk memberikan rekomendasi positif/yang baik. WOM berasal dari suatu pengalaman konsumen yang timbul secara alamiah dan tidak didesain oleh perusahaan juga pemasar, namun timbul karena keunggulan produk atau jasa. Oleh karena itu orang akan lebih mempercayai WOM yang disebarkan oleh konsumen karena konsumen merupakan pihak netral. Seiring berjalannya waktu dan perkembangan teknologi yang pesat kini WOM dapat dilakukan melalui situs internet/media sosial (e-WOM).

E-WOM dan WOM walaupun sejenis tapi tidak dapat disamakan. Menurut penelitian Prayustika (2016), secara keseluruhan, penelitian tersebut menunjukkan bahwa perkembangan teknologi yang pesat mengakibatkan e-WOM jauh lebih unggul daripada WOM.Salah satu alasan yang dikemukakan untuk mendukung pernyataan tersebut adalah karena jangkauan e-WOM lebih besar daripada WOM. Hal ini disebabkan internet dapat 
menghubungkan semua orang dimana saja dengan jumlah tidak terbatas sehingga memiliki kekuatan seperti media massa. E-

WOM menyebabkan terbukanya kesempatan bagi konsumen untuk saling bertukar informasi melalui situs internet. Namun pemasar perlu tahu bahwa e-WOM memiliki risiko yaitu dapat merusak citra suatu dalam sekejap. Wulandari (2017) melakukan penelitian dengan variabel gangguan, kesadaran, dan niat beli. Hasil penelitian yang dilakukannya adalah pemilik usaha harus menghindari annoyance pada jalur komunikasi pemasaran melalui media sosial terutama dalam menampilkan iklan harus menghindari kejenuhan pelanggan. Pemasar harus jeli annoyance mana yang dapat meningkatkan kesadaran merek dan niat beli konsumen dan yang mana yang akan memberikan dampak negatif terhadap kesadaran merek dan niat beli konsumen.

Sari (2012) melakukan penelitian dengan mngumpulkan data dari 100 orang yang belum pernah makan di Restoran Holycow Steak namun pernah memperoleh infonrmasi melalui Twitter. Berdasarkan hal tersebut diperoleh hasil bahwa minat responden terhadap Restoran Holycow Steak tinggi, dengan perolehan mean 4.93 pada kategori "Saya tertarik untuk mencoba menu di Restoran Holycow Steak". Perolehan mean tersebut menunjukan pngaruh e-WOM di media sosial dapat menaikan minat beli konsumen dengan kategori kuat menuju sangat kuat.

Menurut hasil penelitian Firdaus (2017) e-WOM memiliki hubungan kuat dengan keputusan pembelian di restoran yang terdapat di Bandung Utara.Hal ini ditunjukkan dengan nilai koefisien korelasi sebesar 0,689 dan dari persentase pengaruh e-WOM sebesar 47,5\% yang mempengaruhi keputusan pembelian, dansisanya 52,5\% dipengaruhi oleh fakor lain. Hal yang sama terjadi juga pada konsumen di restoran dan kafe Surabaya. Adelia et al., (2014) mengambil responden sebanyak 160 orang dengan responden yang paling dominan adalah wanita sebanyak 90 orang yangberusia 17-35 tahun (sebagian besar masih berstatus mahasiswa). Responden memiliki frekuensi mengunjungi restoran dan kafe sebanyak 1-5 kali hingga 6-10 kali dalam sebulan. Penelitian ini menemukan presentase untuk pengguna e-WOM nilai top two boxes adalah di atas 60\%, sedangkan nilai top two boxes pelaku e-WOM adalah di bawah 50\%. Hasil mean serta top two boxes dan bottom two boxes pengguna e-WOM dapat disimpulkan bahwa responden yang terlibat dalam penelitian terdorong melakukan pembelian direstoran dan kafe di Surabaya setelah mendapatkan informasi berupa e-WOM di situs internet dan media sosial. 


\section{KESIMPULAN DAN SARAN}

Jadi hasil penelitian secara keseluruhan menunjukkan bahwa WOM memiliki peran penting dalam mempromosikan suatu produk. Namun perkembangan teknologi yang pesat memmunculkan bentuk WOM terbaru yaitu e-WOM. Adanya perkembangan teknologi membuat e-WOM jauh lebih unggul dalam mempengaruhi penjualan produk daripada WOM. Hal tersebut terjadi karena banyak hal, salah satunya adalah jangkauan e-WOM yang lebih besar daripada WOM. E-WOM berlangsung di situs internet yang dapat menghubungkan banyak orang tanpa batasan geografis sehingga memiliki kekuatan seperti media massa. Selain itu e-WOM membuat konsumen memiliki banyak kesempatan untuk bertukar informasi melalui situs internet dan media sosial mana pun secara gratis. Melalui e-WOM konsumen bebas berpendapat tanpa diketahui identitas aslinya, sehingga tidak menimbulkan hal berbahaya bagi konsumen saat berpendapat yang negatif. Namun eWOM memiliki risiko yang besar apabila terjadi annoyance/gangguan dari pihak yang ingin menjatuhkan. Risiko yang ditimbulkan dapat membuat penjualan suatu produk berkurang drastis karena berlansgung di media sosial yang dapat dilihat oleh semua orang.

Saran untuk pelaku usaha/pemasar kuliner adalah lebih memperhatikan nama baik perusahaan serta kualitas produk dan layanan agar konsumen merasa puas dan menuliskan ulasan positif di media sosial mengenai produk yang dibelinya. Ketika konsumen menuliskan ulasan positif di media sosial mengenai produk yang dibelinya, secara tidak langsung mereka turu mempromosikan suatu produk. Kemudian melalui media elektronik membuat strategi promosi yang menarik dan kreatif sehingga dapat meningkatkan penjualan kuliner. Hal tersebut dapat menarik minat konsumen lain untuk membeli produk tersebut sehingga konsumen dapat terus bertambah.

\section{DAFTAR PUSTAKA}

Adeliasari, Ivana, V., dan Thio, S. 2014. Electronic Word of Mouth (eWOM) dan Pengaruhnya Terhadap Keputusan Pembelian di Restoran dan Kafe di Surabaya. Manajemen Perhotelan UKP. 2 (2).

Cheung, C. M. K., Lee, M. K. O., dan Rabjohn, N. 2008. The impact of electronic wordof-mouth: The adoption of online opinions in online customer communities. 18 (3).

Dispendukcapil. 2017. http://dispendukcapil.malangkota.go.id/2018/01/lampid2017/.Diakses tanggal21 Maret 2018.

Febiana, D., Kumadji, S., dan Sunarti. 2014. Pengaruh Word of Mouth terhadap Minat Beli serta Dampaknya pada Keputusan Pembelian(Survei pada Pengunjung 
yangMelakukan Pembelian pada Biker's Resto dan Café di Kota Malang). Jurnal Administrasi Bisnis (JAB) UB, 16 (1).

Firdaus, T. 2017. E-WoM : Pengaruhnya terhadap Keputusan Pembelian Tamu Restoran di Bandung Utara. Tourism and Hospitality Essentials (THE) Journal, 7(1).

Goyette, I., Ricard, L., Bergeron, J., dan Marticotte, F. 2010. e-WOM Scale: WordofMouth Measurement Scale for e-Services Context. Canadian Journal of Administrative Sciences, 27 (1).

Hasan, Ali. 2010. Marketing Dari Mulut Ke Mulut. Cetakan 1. Yogyakarta: Media Pressindo.

Kemp, S. 2017. Digital in Southeast Asia in 2017. http://wearesocial.com. Diakses tanggal4 April 2018.

Kotler, P., dan Armstrong, G. 2012. Prinsip-prinsip Pemasaran. Edisi Ketigabelas. Jakarta: Erlangga.

Muarif, S. 2017.Daftar Kota di Jawa Timur Berdasarkan Pendapatan perKapita.http://blogkotakita.blogspot.co.id/2017/02/daftar-kota-di-jawatimurberdasarkan-pendapatan-per-kapita.html. Diakses tanggal 21 Maret 2018.

Nadaraja, R. dan Yazdanifrat, R. 2013. Social Media Marketing: Advantages and Disadvantages. https://www.researchgate.net. Diakses tanggal4 April 2018.

Paludi, S. 2017.Analisis Pengaruh Electronic Word Of Mouth (EWom) terhadap Citra Destinasi, Kepuasan Wisatawan, Dan Loyalitas DestinasiPerkampungan Budaya Betawi (PBB) Setu Babakan Jakarta Selatan. Jurnal STEIN. 11 (1).

Pemerintah Kota Malang. Rumah Makan. https://malangkota.go.id/fasilitasdaerah/rumahmakan/. Diakses pada 21 Maret2018.

Prayustika, P. A. 2016. Manakah yang Lebih Efektif ? Traditional Word of Mouth atau Electronic Word of Mouth. Jurnal Matrix, 6 (3).

Rutmawati, S. 2017. Terungkap, ini alasan bisnis kuliner di kota Malang laris manis. https://malang.merdeka.com/gaya-hidup/terungkap-ini-alasan-bisnis-kuliner-di-kotamalang-laris-manis-170522y.html. Diakses tanggal 21 Maret 2018.

Sari, V. M. 2012. Pengaruh e-WOM di Sosial Media Twitter terhadap Minat Beli Konsumen (Studi pada Restoran Holycow Steak).Jurnal Fisip UI.

Setiawan, S. R. D. 2018. Tahun 2017, Pengguna Internet di Indonesia Mencapai 143.260 .000 Juta Orang. https://ekonomi.kompas.com/read/2018/02/19/161115126/tahun-2017-penggunainternet-di-indonesia-mencapai-14326-juta-orang. Diakses tanggal 21 Maret 2018.

Sumardy, Silviana, M., dan Melone, M. 2011. The Power of Word of Mouth Marketing (Cetakan ke-2 ed.). Jakarta: PT. Gramedia Pustaka Utama.

Watie, E. D. 2011. Komunikasi dan Media Sosial. The Messenger, 3 (1).

Wiyono, Budi. 2009. Pengaruh Word of Mouth Dalam Keputusan Pembelian. Bandung: Kappa Sigma.

Wulandari, N. 2017. Pengaruh Gangguan (Annoyance) dalam Penggunaan Media Sosial pada Kesadaran Merek dan Niat Beli Konsumen (Studi Toko Kue Online Nina's Cake pada Instagram). 